\title{
Serum interleukin 6 levels in rheumatoid arthritis: correlations with clinical and laboratory indices of disease activity
}

\author{
Rajan Madhok, Anne Crilly, John Watson, Hilary A Capell
}

\begin{abstract}
In rheumatoid synovium interleukin 6 (IL-6) is the most abundantly expressed cytokine. Increased serum levels have been previously reported in patients with rheumatoid arthritis (RA). In this study serum IL-6 levels were measured in a well defined cohort using a bioassay (B9 cells) and levels were correlated with conventional clinical and laboratory indices of disease activity.

Levels were significantly higher in serum from patients with RA (median 55 IU/ml; interquartile range 28-139) compared with serum from disease (median 7 IU/ml; 1-23) and normal controls (median $10 \mathrm{IU} / \mathrm{ml}$; 7-12). No difference was observed between men and women. Levels did not correlate with disease duration. Significant associations were observed between IL-6 and C reactive protein and between the Ritchie articular index and duration of morning stiffness. No other correlations were observed. The value of these findings in the monitoring of RA and as an indicator of response to second line treatment needs to be established.
\end{abstract}

(Ann Rheum Dis 1993; 52: 232-234)

Department of Rheumatology Gartnavel and Western Infirmary,

Glasgow,

United Kingdom

R Madhok

Centre for Rheumatic

Diseases,

University Department

of Medicine,

Glasgow Royal

Infirmary,

Glasgow,

United Kingdom

H A Capell

Department of

Biochemistry,

Strathclyde University, Glasgow,

United Kingdom

A Crilly

J Watson

Correspondence to:

Dr R Madhok,

University Department of

Medicine,

Glasgow Royal Infirmary,

10 Alexandra Parade,

Glasgow G31 2ER,

United Kingdom.

Accepted for publication

12 October 1992
Interleukin 6 (IL-6) is the most abundantly expressed cytokine in rheumatoid synovium. ${ }^{1}$ The in vitro activities of this pleiotropic cytokine have been catalogued and several activities previously ascribed to interleukin 1 (IL-1) are now believed to be mediated also by IL-6. In particular IL-6 mediates acute phase protein synthesis and terminal B cell differentiation. $^{2}$

Previous studies have shown that IL-6 levels are higher within synovial fluid than in serum. $^{34}$ In most patients synovial fluid macrophages do not spontaneously produce IL-6, suggesting that IL-6 is derived from cells within the synovium. ${ }^{5}$ Using cytokine probes Firestein et al have shown that synoviocyte IL6 is derived from non-T lymphocytes, type B synovial lining cells and fibroblasts. ${ }^{1}$ Synoviocyte derived IL-6 in patients with rheumatoid arthritis (RA) is enhanced by IL1 and tumour necrosis factor ${ }^{5}$ and can stimulate hepatocyte synthesis of acute phase proteins in vitro.

In this study we measured serum IL-6 levels in a well defined cohort of patients with RA and estimated the in vivo importance of this cytokine in mediating some of the clinical and laboratory changes observed in active RA.

\section{Patients and methods}

PATIENTS

The patients studied consisted of 93 patients with RA seen at one clinic and referred for second line drug treatment. Patients selected for this study did not have coexisting diseases and were not receiving drugs other than nonsteroidal anti-inflammatory drugs (NSAIDs) and analgesics. To avoid any diurnal variations in disease activity all patients were seen in the morning.

\section{CONTROLS}

Normal controls matched for age and sex were selected from a general population survey determining risk factors for coronary artery disease. Disease controls included patients with osteoarthritis receiving analgesics and NSAIDs.

CLINICAL ASSESSMENTS

All clinical assessments were made by an independent nurse familiar with clinical trial methodology and included the Ritchie articular index, duration of morning stiffness in minutes, and pain score rated on a $10 \mathrm{~cm}$ visual analogue scale.

\section{LABORATORY ASSESSMENTS}

These included erythrocyte sedimentation rate (Westergren), full blood count, platelets (Coulter S) and serum $C$ reactive protein (CRP) measured by laser nephelometry. Serum samples for subsequent determinations of IL-6 were stored at $-20^{\circ} \mathrm{C}$.

INTERLEUKIN 6 ASSAY

An IL-6 dependent cell line was used (B9). The cells were maintained as previously described with one modification: hybridoma growth factor (Cambio, Cambridge, United Kingdom) was used instead of stimulated human mononuclear cell supernatant. ${ }^{6}$ The assay was carried out in 96 well flat bottomed microtitre plates. A total of $5000 \mathrm{~B} 9$ cells/well were cultured in RPMI 1640 containing antibiotics, $5 \%$ heat inactivated fetal calf 
serum, $5 \times 10^{-5} \mathrm{M}$ mercaptoethanol, and serial twofold dilutions of heat inactivated test serum. Proliferation was assessed using a spectrophotometric method after a 72 hour incubation in a $5 \% \quad \mathrm{CO}_{2}$ /humidified atmosphere. Each dilution was tested in triplicate. Test sample IL-6 values (IU/ml) were calculated from a standard curve obtained using a reference preparation known to contain

Table 1 Clinical and laboratory indices of disease activity

\begin{tabular}{lc}
\hline Disease activity parameter & $\begin{array}{l}\text { Value } \\
\text { (median (interquartile range)) }\end{array}$ \\
\hline Haemoglobin $(\mathrm{g} / \mathrm{l})$ & $121(109-129)$ \\
White cell count $\left(\times 10^{9} / \mathrm{l}\right)$ & $7 \cdot 9(6 \cdot 6-9 \cdot 2)$ \\
Platelets $\left(\times 10^{9} / \mathrm{l}\right)$ & $392(336-489)$ \\
$\mathrm{ESR}^{\star}(\mathrm{mm} / \mathrm{hour})$ & $48(30-70)$ \\
$\mathrm{CRP}^{\star}(\mathrm{mg} / \mathrm{l})$ & $34(16-67)$ \\
Ritchie articular index & $12(9-19)$ \\
Morning stiffness (minutes) & $90(30-180)$ \\
Pain $(\mathrm{cm})$ & $5(2-7)$ \\
\hline
\end{tabular}

$\star E S R=$ erythrocyte sedimentation rate; $C R P=C$ reactive protein.

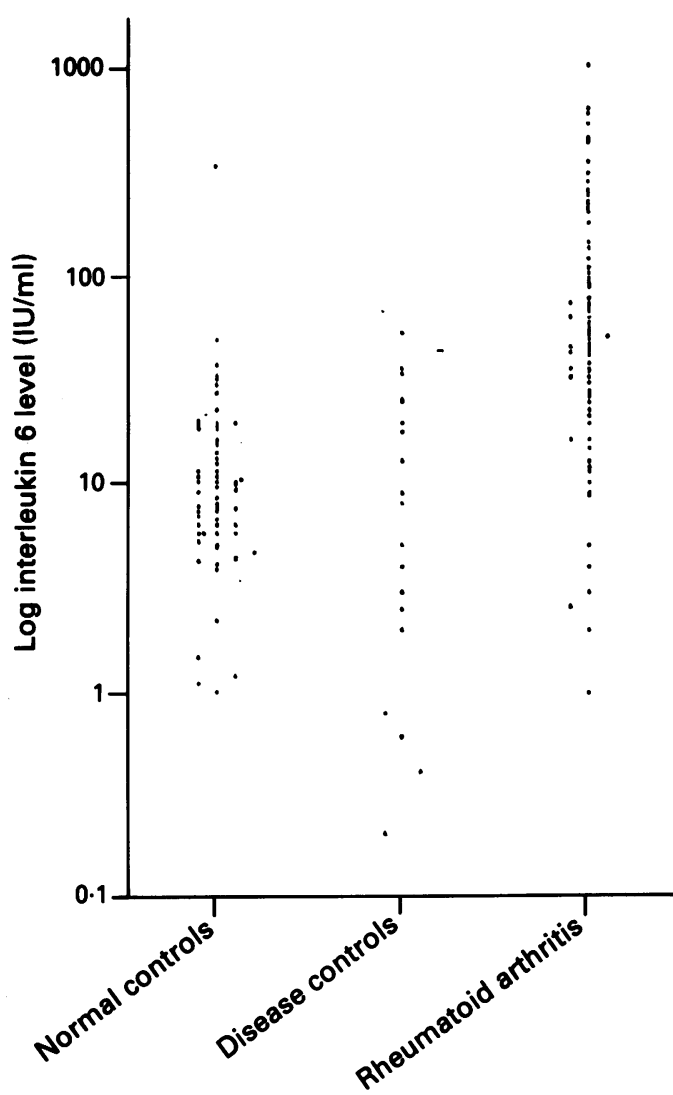

Interleukin 6 levels were measured in 70 normal controls, 20 patients with osteoarthritis as disease controls, and 93 patients with $R A$. There was no difference in levels between normal and disease controls. Levels were higher in patients with $R A$ than in normal and disease controls.
$400 \mathrm{IU} / \mathrm{ml}$ of IL-6 (Cambio). Relative to an international IL-6 standard (National Institute for Biological Standards, United Kingdom, IL-6 standard Ref. No 88/514) our reference preparation had $91 \%$ of the IL-6 activity quoted by the manufacturer.

To confirm that the assay was measuring IL-6, neutralisation studies of random test serum samples were undertaken using a goat polyclonal antibody to IL-6 (British Biotechnology, Oxford, United Kingdom). The antibody $(10 \mathrm{mg} / \mathrm{ml})$ was serially diluted in RPMI 1640 in microtitre plates. To each well $50 \mu \mathrm{l}$ of heat inactivated serum was added to a final volume of $100 \mu \mathrm{l}$. Plates were incubated for one hour at $37^{\circ} \mathrm{C}$. The IL-6 activity was then measured in a $50 \mu$ l aliquot of neutralised serum as described.

\section{STATISTICAL METHODS}

The median and interquartile ranges are reported. Spearman rank correlation coefficients were calculated for all variables measured. The Mann-Whitney U test was used to estimate the differences between groups.

\section{Results}

The median age of the 93 patients studied was 56 years (interquartile range 47-67) with a median disease duration of eight years (range 3-15). Of the patient group 71 were women. All patients had active synovitis and table 1 gives parameters of disease activity.

\section{INTERLEUKIN 6 LEVELS}

In our laboratory the lower limit of IL-6 activity detected by B9 cells was $0 \cdot 15 \mathrm{IU} / \mathrm{ml}$ ( 2 $\mathrm{pg} / \mathrm{ml}$ ). The intra-assay and interassay precision values of the assay were 14 and $18 \%$ respectively. The IL-6 activity could be completely neutralised in samples from patients with RA using an IL-6 antibody.

Serum IL-6 values were significantly higher in patients with RA (median $55 \mathrm{IU} / \mathrm{ml}$; 28-139) than in disease (20 subjects, median $7 \mathrm{IU} / \mathrm{ml} ; 1-23) \quad(\mathrm{p}<0.0001)$ and normal controls (70 subjects, median $10 \mathrm{IU} / \mathrm{ml} ; 7-12$ ) $(\mathrm{p}<0.0001)$ (figure). There was no difference in IL-6 values between men (median $71 \mathrm{IU} / \mathrm{ml}$; 33-219) and women (median $52 \mathrm{IU} / \mathrm{ml}$; 28-111) with RA ( $p=0 \cdot 3)$.

There was no correlation between IL- 6 and age in patients with $\mathrm{RA}(\mathrm{r}=-0 \cdot 1 ; \mathrm{p}=0 \cdot 2)$ or normal controls (data not shown) or in disease

Table 2 Spearman rank correlations between laboratory and clinical variables measured. Numbers given are $r(p)$ values. Serum Il-6 values showed some association with serum $C$ reactive protein levels, Ritchie articular index, and pain

\begin{tabular}{|c|c|c|c|c|c|c|c|c|c|}
\hline & $I L-6$ & $H g b$ & $W B C$ & $P L T$ & $E S R$ & $C R P$ & $R A I$ & $A M S$ & Pain \\
\hline $\begin{array}{l}\text { IL-6 } \\
\text { Hgb } \\
\text { WBC } \\
\text { PLT } \\
\text { ESR } \\
\text { CRP } \\
\text { RAI } \\
\text { AMS }\end{array}$ & & $-0.06(0 \cdot 6)$ & $\begin{array}{l}0.05(0.6) \\
0.3(0 \cdot 01)\end{array}$ & $\begin{array}{c}0 \cdot 1(0 \cdot 3) \\
-0 \cdot 4(0 \cdot 001) \\
0 \cdot 4(0 \cdot 001)\end{array}$ & $\begin{array}{l}0.2(0.1) \\
-0.6(0.001) \\
-0.00(0.9) \\
0.5(0.001)\end{array}$ & $\begin{array}{c}0 \cdot 2(0 \cdot 05) \\
-0 \cdot 5(0 \cdot 001) \\
0 \cdot 2(0 \cdot 09) \\
0 \cdot 6(0 \cdot 001) \\
0 \cdot 7(0.001)\end{array}$ & $\begin{array}{c}0 \cdot 3(0 \cdot 01) \\
-0 \cdot 05(0 \cdot 6) \\
-0 \cdot 1(0 \cdot 2) \\
0 \cdot 03(0 \cdot 7) \\
-0 \cdot 01(0 \cdot 9) \\
-0 \cdot 06(0 \cdot 6)\end{array}$ & $\begin{array}{l}0 \cdot 2(0 \cdot 03) \\
-0 \cdot 01(0 \cdot 9) \\
0 \cdot 1(0 \cdot 2) \\
0 \cdot 2(0 \cdot 06) \\
0 \cdot 04(0 \cdot 6) \\
0 \cdot 2(0 \cdot 1) \\
0 \cdot 4(0 \cdot 003)\end{array}$ & $\begin{array}{c}0.0(0 \cdot 1) \\
-0.04(0 \cdot 7) \\
-0.00(0.9) \\
0.1(0 \cdot 3) \\
0.01(0.9) \\
-0.08(0.4) \\
0 \cdot 1(0 \cdot 3) \\
0.1(0.3)\end{array}$ \\
\hline
\end{tabular}


duration $(\mathrm{r}=-0.08 ; \mathrm{p}=0.4)$. Table 2 gives correlations between IL- 6 and disease activity parameters.

\section{Discussion}

The observations in this study extend results of previous studies showing increased levels of IL-6 in serum and synovial fluid from patients with RA. ${ }^{3478}$ We confirm that serum IL-6 values are increased in $\mathrm{RA}$, are independent of age, duration of $\mathrm{RA}$, and patient gender. Of the laboratory indices measured, only IL- 6 showed an association with the Ritchie articular index. Serum IL-6 values account for only $9 \%$ of the variation in the Ritchie articular index, however. A better association might have been obtained if an articular index taking into account joint surface area $a^{9}$ or a more sensitive indicator of joint disease such as radionuclide joint scanning had been used. ${ }^{10}$ No associations were observed with duration of morning stiffness and pain score. We and others have shown that IL- 6 levels can be modulated by sodium aurothiomalate. ${ }^{11} 12$

Two additional observations of interest were noted. : Firstly, IL-6 levels were weakly associated with CRP concentrations and, secondly, there was no correlation with platelet count. In vitro studies show that IL- 6 is the principal cytokine driving hepatocyte acute phase protein synthesis. ${ }^{2}$ We found that in vivo IL-6 accounts for only 4\% of CRP values, a finding similar to that observed by Holte et al. ${ }^{7}$ A similar poor association was apparent between IL-6 and fibrinogen, another acute phase reactant, in our control population. Houssiau et al have, however, reported a better association between IL- 6 and CRP. ${ }^{3}$ The reasons for the difference in findings may be due to differences in the assays used, a smaller number of patients studied or a selection bias.

Our findings suggest that in vivo acute phase protein synthesis may be due to several cytokines acting sequentially or together to modulate acute phase protein synthesis. In support of this Gatner et al have reported that in vitro IL- 1 and IL-6 have a synergistic effect on hepatocyte CRP expression ${ }^{13}$ and transforming growth factor $\beta$ inhibits the expression of some acute phase reactants induced by IL- $6 .{ }^{14}$

The poor correlation between IL-6 and platelet count was also surprising as this cytokine shows some homology with thrombopoietin, has the capacity to induce megakaryocyte maturation in vitro synergistically with interleukin-3, and increases the platelet count in experimental animals (reviewed by Hirano $^{12}$ ). A similar poor association between IL-6 and secondary thrombocytosis has been reported elsewhere. ${ }^{15}$ Therefore in patients with RA thrombopoietic factors other than IL-6 appear to be more important.

In conclusion, the results of this study show that of the laboratory parameters measured only IL-6 showed some association with the Ritchie articular index. The value of this observation in monitoring patients with RA and selecting those suitable for second line drug treatment needs to be determined further in a routine clinical setting and in trials of disease modifying drugs. Some of our observations were contrary to those that would be predicted from the in vitro effects of this cytokine, confirming the complexity of the cytokine network in vivo.

AC is funded by the Secretary of State's Office for Scotland. Supported by the Arthritis and Rheumatism Council (UK).

1 Firestein G S, Alavro-Garcia J M, Maki R. Quantitative analysis of cytokine gene expression in rheumatoid arthritis. F Immunol 1990; 144: 3342-53.

2 Hirano T. Interleukin-6. In: Thomson A, ed. The cytokine handbook. London: Academic Press, 1991: 169-91.

3 Houssiau F A, de Vogelaer J P, van Damme J, de Deuxchaisnes $C \mathrm{~N}$, van Snick J. Interleukin-6 in synovial fluid and serum of patients with rheumatoid arthritis and other inflammatory arthritis. Arthritis Rheum 1988; 31: other infir.

4 Bhardwaj N, Santhanam U, Lau L L, et al. IL-6/IFN $B_{2}$ in synovial effusions of patients with rheumatoid arthritis and other inflammatory arthritidies. F Immunol 1989; 143: 2153-9.

5 Gurne P A, Zuraw B L, Vaughan J H, Carson D A, Lotz M. Synovium as a source of interleukin-6 in vitro. $\mathcal{f}$ Clin Invest 1989; 83: 585-92.

6 Helle M, Boeije L, Aarden L A. Functional discrimination between interleukin-6 and interleukin-1. Eur $\mathcal{f}$ Immunol 1988; 18: 1535-40.

7 Holte I, Cooper R G, Hopkins S J. Relationships between local inflammation, interleukin- 6 concentration and the acute phase response in arthritis patients. Eur $\mathcal{F}$ Clin Invest 1991; 21: 479-84.

8 Swaak A J, Van Rooyen A, Nieuwenhuis E, Aarden L A. IL-6 in synovial fluid and serum of patients with rheumatic diseases. Scand $\mathcal{F}$ Rheumatol 1988; 17: 469-74.

9 Thompson P W, Kirwan J R, Currey H L F. Articular indices of joint inflammation in rheumatoid arthritis. Correlation with the acute phase response. Arthritis Rheum 1987; 30: 618-23.

10 Mottonen $\mathrm{T} T$, Hannonen $\mathrm{P}$, Toivanen J, Rekonen A, Oka M. Value of joint scintigraphy in prediction of erosiveness in early rheumatoid arthritis. Ann Rheum Dis 1988; 47: 183-9.

11 Madhok R, Crilly A, Murphy E, Smith J, Watson J, Capell $\mathrm{H}$ C. Gold therapy lowers interleukin-6 levels in rheumatoid arthritis. $\mathcal{F}$. Rheumatol. In press.

12 Dasgupta B, Corkill M, Kirkham B, Gibson T, Panayi G. Serial estimation of interleukin 6 as a measure of systemic disease in RA. $\mathcal{F}$ Rheumatol 1992; 19: 22-6.

13 Gatner U, Arcone R, Toniatti C, Morrone G, Ciliberto G. Dual control of C-reactive protein gene expression by interleukin-1 and interleukin-6. EMBO $\mathcal{f} 1989$; 8: interleukin

14 Mackiewicz A, Ganapathi M K, Schultz D, et al. Mackiewicz A, Ganapathi $M \mathrm{~K}$, Schultz $\mathrm{D}$, et al.
Transforming growth factor beta-1 regulates production of acute phase proteins. Proc Natl Acad Sci USA 1990; 87: 1491-5.

15 Hollen C W, Hentthron J, Koziol J A, Burstein S A. Elevated serum interleukin-6 levels in patients with reactive thrombocytosis. Br $\mathcal{F}$ Haematol 1991; 79: 286-90. 